\title{
Work, authority and participation : the scenario of circular organizing
}

Citation for published version (APA):

Romme, A. (1997). Work, authority and participation : the scenario of circular organizing. NIBOR, Netherlands Institute of Business Organization and Strategy Research. NIBOR Research Memorandum No. 01 https://doi.org/10.26481/umanib.1997001

Document status and date:

Published: 01/01/1997

DOI:

10.26481/umanib.1997001

Document Version:

Publisher's PDF, also known as Version of record

\section{Please check the document version of this publication:}

- A submitted manuscript is the version of the article upon submission and before peer-review. There can be important differences between the submitted version and the official published version of record.

People interested in the research are advised to contact the author for the final version of the publication, or visit the DOI to the publisher's website.

- The final author version and the galley proof are versions of the publication after peer review.

- The final published version features the final layout of the paper including the volume, issue and page numbers.

Link to publication

\footnotetext{
General rights rights.

- You may freely distribute the URL identifying the publication in the public portal. please follow below link for the End User Agreement:

www.umlib.nl/taverne-license

Take down policy

If you believe that this document breaches copyright please contact us at:

repository@maastrichtuniversity.nl

providing details and we will investigate your claim.
}

Copyright and moral rights for the publications made accessible in the public portal are retained by the authors and/or other copyright owners and it is a condition of accessing publications that users recognise and abide by the legal requirements associated with these

- Users may download and print one copy of any publication from the public portal for the purpose of private study or research.

- You may not further distribute the material or use it for any profit-making activity or commercial gain

If the publication is distributed under the terms of Article $25 \mathrm{fa}$ of the Dutch Copyright Act, indicated by the "Taverne" license above, 
Work, authority and participation: The scenario of circular organizing

A.G.L. Romme

NIBOR/RM/97/01

http://www.unimaas.nl/ document/fdewb.htm

J.E.Lit. code: $\mathrm{M} 10$

$n i b \circ r$

Netherlands Institute of

Business Organization

and Strategy Research

University of Maastricht

Faculty of Economics and Business Administration

P.O. Box 616

6200 MD Maastricht

The Netherlands

Phone: ++3143 - 3883805 
Fax : ++3143-3258495

Work, Authority and Participation:

\title{
The Scenario of Circular Organizing
}

\author{
A. Georges L. Romme \\ Department of Management Sciences \\ Maastricht University, P.O. Box 616 \\ 6200 MD Maastricht, Netherlands
}

Tel: 31-43-3883807

Fax: 31-43-3258495

email: S.ROMME@MW.UNIMAAS.NL 
Two antagonistic tendencies in the way work is organized can be observed in Europe and the North-American continent. First, there is the growing tendency toward more efficient and flexible modes of organizing by way of a clear (re)distribution of authority. At the other hand, the importance of participation and cooperation in the workplace is growing, also in view of ideas about empowerment, organizational democracy, and self-management. The purpose of this paper is to explore the possibility of organizing work in a circular manner, based on a synthesis of traditional and participative work relationships. Circularity implies that an ultimate authority in the workplace is absent and each member of the organization can participate directly or through representation in decision-making. Design precepts for organizing in a circular manner are discussed, and some implications for the role of authority and participation in the (postmodern) workplace are explored. 


\section{Work, Authority and Participation: The Scenario of Circular Organizing}

\section{INTRODUCTION}

The 1980s and 1990s have been remarkable in the sense that two contrasting tendencies in the way work is organized and controlled have been, and still are, developing in Europe and the North-American continent. The first one is a tendency toward more efficient and flexible work relationships, typically imposed on the organization by those who have the authority to do so. The other tendency involves a shift to participative and cooperative governance in the workplace. This article explores the possibility of a synthesis of traditional and participative work relationships by organizing work in a circular manner. Circularity implies that although authority continues to play an important role in the workplace, an ultimate authority is absent, and each member can participate directly or through representation in decision-making.

\section{The Return to Authority in the Workplace}

The tendency toward more cost-efficient and flexible modes of organizing is most evident in attempts to downsize the work force (Atchison, 1991). In order to meet this kind of objectives, the role of employees is therefore increasingly (re)captured in terms of clear authority structures. In this respect, several authors have pointed at certain benefits of the authoritarian system which may be the only effective organizational device for managing large numbers of people which also preserves unambiguous accountability for the work they do (Carley, 1992; Jaques, 1990).

Authority in the workplace is based on the conditions agreed upon in the employment contract - be it individual or collective, tacit or written - which implies an unequal division of authority: the employee sells (the right to decide over) his or her labor power to the employer who in exchange undertakes to pay out a certain remuneration (Knudsen, 1995).

The fundamental insecurity arising from authoritarian employment relationships tends to be detrimental to employees' mental health and decreases productivity and morale (Hartley et al., 1991; Hirschhorn, 1990). Other implications or side-effects of the traditional employment contract that have been observed are employees becoming less cooperative, more aggressive, less satisfied, and alienated from their work (Baron and Neuman, 1996; Blauner, 1964; Collinson, 1994; O'Connell-Davidson, 1994; Ouchi, 1981; Voyer, 1994). These observations can be explained by looking at the underlying system: if managers apply their authority no matter what the situation, they in effect (re)produce a system in which people are either dependent and submissive, or rebellous; vice versa, if employees 
remain silent, dependent and submissive, or become rebellous, they in effect (re)produce a system in which managers have to act on the basis of authority.

\section{The Shift to Participation}

Another tendency in how work is organized involves a shift to participative and cooperative governance in the workplace (Atchison, 1991; Katzner, 1995). This shift appears to be both inevitable and necessary, also in view of ideas about empowerment, organizational democracy, self-management and total quality management. Participative governance is inevitable because the capacity for participation is already widespread and will continue to grow, but is also necessary because the issues faced tend to be too complex and interdependent to be solved by a few people in authority (McLagan and Nel, 1995). Most actual attempts to stimulate participation in the workplace, including quality circles and semi-autonomous teams, have been aiming at partial participation, leaving the underlying authority structure unaffected. In general, the move toward participation in the workplace has therefore shown greater diffusion at the level of principle than of practice (Stewart and Manz, 1995; Wall, 1982). Thus, the kind of fundamental change that would dramatically increase quality, productivity and customer awareness remains elusive, not because partial participation programs are wrong, but because they have not been propelled by a new vision of institutional governance based on the idea of fully participative work relationships (McLagan and Nel, 1995).

In order to be effective, this new vision would have to incorporate the role of authority, because one cannot escape from the reality of the role of authority in organizations. Moreover, authors advocating more participation in the workplace tend to disregard the positive quality of the authoritarian system (Iannello, 1992; McLagan and Nel, 1995; Peters, 1987).

In this respect, many authors assume participative and authoritarian work relations in their pure forms are incompatible, basically because you cannot advocate participation and have bosses continue to manage the workplace (Dahl, 1989; Hedlund, 1994; Manz and Sims, 1987; Mulder, 1971; Vaughan, 1983; McLagan and Nel, 1995).

\section{Domination versus Self-determination}

At a more deeper level, the contradiction between the return to authoritarian systems and the shift to participative systems may arise from different concepts of power implicated by these two generic systems. Authority in the workplace implies the concept of domination, that is, power over others in terms of the capacity of one actor to carry out his own will despite resistance of other people, for example, to get these people to do things they would not otherwise do (Clegg, 1989; Pfeffer, 1992). By contrast, participation is based on an entirely different concept of power, selfdetermination, which involves the power to act autonomously when people are capable to negotiate, decide and act together voluntarily (Dahl, 1989; Emery, 1980). The concept of self-determination is inextricable from the idea of 
democracy (Emery and Thorsrud, 1976), and, following Dahl, self-determination in its pure form would make domination "impossible (or at any rate illegitimate), since any group facing coercion on any matter could demand and through secession gain autonomy" (Dahl, 1989, p. 196-97).

\section{THE EMERGENCE OF CIRCULAR FORMS OF ORGANIZING}

Given the argument thusfar, the exploration of a synthesis between authoritarian and participative systems should start with a new concept of power that integrates the thesis of domination with self-determination as its anti-thesis.

In the US the idea of circularity has been explored extensively by Ackoff $(1981 ; 1989 ; 1994)$. Ackoff's early work in this area was triggered by his search for an organizational design that supports interactive planning processes. He proposed all people with authority in organizations, from the chief executive to the supervisor, should have boards made up of their immediate superiors and subordinates to create a circularity of responsibility and accountability. The board at any given level is responsible for planning and coordinating the work for which that person is responsible, and also for reviewing and evaluating his or her performance, and should according to Ackoff (1981) decide by majority vote. In sum, Ackoff's model of circular organizing involves two modes of organizing - the administrative hierarchy and the boards - but leaves open the issue of how these different modes should be linked.

Companies such as Kodak, Alcoa, Anheuser-Busch and A\&P Supermarkets have applied Ackoff's ideas, although the precise form is said to vary significantly from organization to organization (Ackoff, 1989). Studies of these or other organizations using Ackoff's ideas are not available, but on the basis of experiences in these organizations (not described in any detail), Ackoff recently argued boards should operate by consensus rather than majority rule: "Boards should prepare their own operating procedures, but most of them operate in much the same way. Most, for example, operate by consensus rather than majority rule. The advantages of consensus over split decisions are apparent. The principal advantage is that it removes the possibility of a tyranny of the majority, the type of tyranny most frequently encountered" (Ackoff, 1994, p. 133). Ackoff's concept of circular organizing can be summarized as a 'democratic hierarchy' having three essential characteristics: the absence of an ultimate authority; the ability of each member to participate directly or through representation in all decisions that affect him or her directly; and the ability to make and implement decisions that affect no one other than the decision makers (Ackoff, 1994).

The idea of circularity has also emerged in Europe, especially in several organizations in the Netherlands (Endenburg, 1988; Van Vlissingen, 1991; Romme, 1996). Noteworthy in this form of circular organizing, in the Netherlands also known as sociocratic organizing, is the use of 'double linking' between hierarchically ordered teams or 'circles'. Double linking implies that a team is linked to the next higher team in the hierarchy by means of, first, its functional leader (e.g., supervisor) who is appointed by the next higher team, and second, a representative or 
spokesman who is elected within the team. The representative participates in decision-making in the next higher team, together with the hierarchical leader who also remains responsible for supervising the work process in the team (Endenburg, 1988; Van Vlissingen, 1991). As such, double linking may provide guaranteed representation upward, without a substantial erosion of the authority of the leader, and may promote both downward and upward communication between teams (Van Vlissingen, 1991).

The emergence of circular forms of organizing raises fundamental questions about the possibility to synthesize authority and participation as governance principles. In this respect, circularity implies the capacity to switch between authority and participation, and, as such, is based on feedback rather than power as the key organizing principle (Romme, 1995). Compared to the Ackoff model of circular organizing, the Dutch model has developed into a system of well-defined principles and procedures. In addition, it has recently also been introduced in organizations outside the Netherlands, for example, in Brazil, Canada and the US (Reijmer and Romme, 1996), which suggests it may not be biased toward exclusive Dutch institutional or cultural conditions.

\section{$\underline{\text { Background }}$}

The development of the circular organization in the Netherlands has been initiated by Gerard Endenburg who began experimenting in the early 1970s with circular ideas in Endenburg Elektrotechniek, a medium-sized company working in the area of the design, production, installation and renovation of electrotechnical installations, control systems, switching boards, and other electronic instruments. In these experiments Gerard Endenburg used ideas from two sources. The first source was the Dutch educational and social theorist Kees Boeke who consistently applied Quaker consensus principles in organizing and administering his primary, secondary and high school, in which Endenburg was enrolled for a period of more than ten years. In this respect, the Quaker tradition recognizes that the best solution to important problems will in all likelihood come out of the collective wisdom of those closest to the problem, regardless of their formal position (Louis, 1994).

The second source inspiring Endenburg in his initial experiments was systems theory. After high school, Endenburg was trained as an electrical engineer and thus became familiar with (technical) systems theory, and in particular, the distinction between between linear and non-linear dynamic systems. In linear systems, information flows in one direction only, whereas in a non-linear system, information flows in two directions.

Inspired by the idea of consensus decision-making and ideas about non-linear systems from engineering, Endenburg started to develop the model of circular organizing. First, he adapted the Quaker consensus principle of full agreement to consent, or the "absence of any argued objection". In other words, where a consensus decision is arrived at when all say 'yes', for a consent decision it is sufficient that no one says 'no'. The possibility to raise objections would give each individual employee the power to influence and control his own work environment, whereas the emphasis on the arguments behind objections was also expected to stimulate creative solutions. 
Other elements were also derived by analogy from systems theory. Endenburg found that organizations are typically viewed with a linear image in mind, that is, we tend to assume that power flows from top to bottom. From an engineering viewpoint, however, organizations are severely hampered by their linear management structure, and therefore Endenburg decided to create a dynamic structure, in which feedback rather than power is the key organizing principle.

\section{$\underline{\text { Outline of Circular Design Precepts }}$}

The circular model, as it currently operates in about twenty Dutch and four non-Dutch organizations, involves the following four principles (Endenburg, 1988; 1992).

Decision-making about policy at all levels is governed by consent, defined as "no argued objection". This principle implies the reasons and arguments offered are of prime importance, and a decision is made when each participant gives consent. Note that only policy decisions are made by consent. In general, consent decision-making allows the application of other decision methods, as long as this is agreed upon by consent. Thus, decisions about implementation of policy are in Endenburg Elektrotechniek typically delegated to line managers or supervisors (as functional leaders), although other methods such as majority rule could also be used.

Every member of the organization belongs to at least one circle, a work unit. A circle is a group of people with a common work objective whose basic mode of policy decision-making is consent (see first principle). The circle includes the functional leader (e.g., supervisor or manager) of the work process administered by that circle. Consent decision-making normally occurs in specially scheduled meetings. Circle meetings decide about decision topics which are relevant to the work objectives of the circle and which are within the limits of the circle's authority, that is, the policy domain of the circle.

Double linking between hierarchically ordered circles. The organization, if large enough, subdivides into a hierarchy of circles in which each lower circle is double linked to the next higher circle. That is, each circle is represented in the next higher circle by the functional leader (supervisor or manager) and one or more additional representative(s) chosen from the circle by consent. Double linking extends Likert's (1976) well-known 'linking pin' principle, which suggests that the functional leader participates in decision-making in his own unit as well as at the next higher hierarchical level. The double linking principle adds another linkage between these two levels, which is similar to Likert's linkage - the representative participates in decision-making at both levels - but complementary in terms of power flow: the representatives are chosen at the lower level (bottom up) whereas functional leaders are appointed by the next higher hierarchical level (top down).

Election of persons by consent after open discussion. This principle implies each circle assigns its membership by consent to the positions and tasks required to realize the circle's work objectives by way of an open discussion. As 
such, it logically follows from the former three precepts. However, the transition from traditional toward circular organizing tends to be most evident in elections. Important elections in each circle involve the circle's chair, representative(s) to the next higher circle, and functional leaders. People tend to be reluctant about discussing other persons in public, especially when they are present, because the practice of most democratic systems suggests secret voting is the best way to deal with elections. An election by consent emphasizes the importance of arguments raised in favor of certain candidates.

\section{$\underline{\text { Implications of Circular Organizing }}$}

The implementation of these precepts implies the administrative hierarchy, and the control instruments typically used (e.g., direct supervision, activity control, output measurement), are integrated into the circular structure. The circular structure is superimposed on the administrative hierarchy, and can thus correct any problems arising in the context of work processes governed on the basis of authority. Figure 1 shows a typical circular structure which is superimposed over the administrative hierarchy. Each unit circle includes all members of the unit. The general circle includes, for example, the general manager (or CEO), unit managers, and (at least) one representative chosen from each unit circle. The membership of the top circle includes the general manager, one or more representative(s) from the general circle, and several outside members (cf. directors). Figure 1 shows the basic form of a circular structure, which can be adapted to the needs of larger or more complex hierarchies, for example, by adding an additional layer of circles or by delegating certain temporary projects to so-called support circles (which are similar to project teams).

Figure 1 here

\section{AUTHORITY, PARTICIPATION, AND CIRCULARITY}

The argument in the previous section suggests the circular model is a practical model for regulating the workplace, based on a new concept of power which synthesizes the role of authority and participation. Several implications for some of the most sensitive areas in organizational life will now be explored: the issue of policy making, the allocation of positions and tasks, the role of employment contracts, and the issue of ownership.

\section{The Issue of Policy Making}

In an authoritarian system, work tends to be divided in a rather straightforward manner: managers think and employees do. Thus, the formulation of strategic and business policy and the implementation of policy are separate activities (Daft and Macintosh, 1984). In participative systems such as worker co-operatives, people with different 
roles sit together to discuss about and decide on all (policy) issues.

In a circular system there are two modes of organizing: the circular mode and the hierarchical mode. Circles are the places where policy is made, with each circle level focusing on a different level of abstraction and accountability (e.g., work processes in unit circles, competitive strategy in the general circle, and the long-term viability of the organization in the top circle). Part of this ongoing policy process is the (re)construction and use of the administrative hierarchy, for example, by delegating certain tasks from the general circle to a unit circle or to the general manager. Thus, it appears that the circular organization may be able to combine the benefits of the administrative hierarchy with the advantages of horizontal, team-like processes in circles.

\section{Allocating Positions and Tasks}

In an authoritarian system, executives are appointed by the Board, middle managers are appointed by the executives, and middle managers allocate tasks to the employees in their work unit. In a participative system, executives and managers are appointed in a democratic or consensual manner from the membership of the organization, and tasks are also allocated in a team-like fashion. In a circular system, managers are elected through a participative and open decision-making process in the next higher circle. That is, the top circle appoints (by consent) the general manager, and the general circle appoints the unit managers. At the same time, representatives are chosen in a bottom up manner (from unit to general circle, and from general to top circle). These two similar processes of top-down election of leaders and bottom-up elections of representatives increases the problem solving capacity of the whole system, for example, with regard to potential misfits between persons and positions, or any other problems that may arise in authoritarian or participative systems.

\section{Employment Contracts, Partnership, and Circularity}

Authority in the workplace is based on the employment contract which implies the employee sells (the right to decide over) his or her labor power to the employer. The shift to participation in the workplace, however, would require a kind of partnership contract with all employees.

Authority and partnership can be reconciled as follows. Each employee has an employment contract with the organization, and at the same time they participate in decision-making about their circle's policy, including decisions to recruit new employees or untie existing employment relationships. For example, when an employee repeatedly fails to perform, anyone in the circle accountable for this employee can propose to untie the relationship with the employee in question. The procedure in such a case is that this employee is invited to participate in the discussion on this proposal during the circle meeting, in order to be able to hear his side of the story, but has no say in the final decision. In other words, a circle member does not have the right to object in case of decisions about his contract with the circle. A decision to untie the relationship between employee and unit circle may lead the general circle to explore any 
opportunities to place this employee in another circle, before a final decision about ending the employment contract is taken. In general, this procedure appears to combine the benefits of partnership in the workplace with the employment contract as one of the key elements of the market economy.

\section{$\underline{\text { Ownership and Circularity }}$}

The idea of circularity of power also has major implications for the relationship between (e.g., stock) owners and the organization. The traditional ownership situation is based on the assumption that the financial owner is and should be the ultimate authority in the workplace. This idea underlies most legal forms currently in use (corporation, partnership, foundation) but is highly contingent on the scarcity of financial capital relative to other means of production. These other means, particularly the knowledge of workers, have become as important as capital (Zeleny, 1989), and can only be exploited by acknowledging the need for learning and participation at all organizational levels.

The circular model implies financial owners should be able to influence decision-making in the top circle (cf. Board of Directors), but not at the cost of the influence of other interests. Currently there is no legal form available which supports this idea. Therefore, several companies which have introduced circular organizing in the Netherlands have created a solution by combining the corporation and foundation in one hybrid legal entity. In this legal structure the foundation owns all stock in the corporation, and as such controls the company from a financial perspective. The constitution of the foundation is based on the same design precepts as the corporation's constitution, and according to both constitutions the top circle of the corporation automatically also acts as the top circle of the foundation. This top circle includes at least one external member (director), representing the interests of stock owners. This legal construction is formally accepted by the Dutch government, but in view of its hybrid character a new 'circular' legal form is now being developed.

\section{CONCLUDING REMARKS}

The emergence of circular organizing can be understood as the start of an interesting new scenario for the future of work organization. This scenario grew out of dissatisfaction with two trends in the organization of work - the return to authority and the shift to participation - and intends to combine the benefits of authoritarian and participative systems. By superimposing a consent-based circular structure on the hierarchical structure, organizations are redefined in terms of human systems which are controlled by way of participative processes rather than on the basis of an ultimate authority derived from (external) ownership.

The notion of power is redefined accordingly. Whereas most social science literature tends to view power as something given and relatively fixed (Clegg, 1989; Hardy and Clegg, 1996), in the context of a circular system power acquires another quality. First, the circular model stresses the relational quality of power, that is, the use of power can be controlled and corrected at all levels in the organization by a circular structure which governs the hierarchical 
structure. Second, the circular model facilitates the process of representation of power by providing a forum where the use and allocation of power can be discussed. At the same time, the hierarchy continues to play an important role, which may prevent the kind of excesses participative system tend to bring about (e.g., too much talk and too few actions).

In this respect, the circular model to some extent reflects a post-modern view which stresses the relational quality of power, the representation of power, and the fixing of power (Clegg, 1989). However, it also undermines the typical post-modern world view which is highly critical of any attempt to recast power relationships (Jermier, Knights and Nord, 1994; Hardy and Clegg, 1996). As such, the circular model is based on the idea that the antagonism between domination and self-determination, and thus between authority and participation, can be usefully overcome. The circular model of workplace governance may therefore help to create more human conditions in the workplace without automatically producing a conflict of interest between authority and participation. 


\section{References}

Ackoff, R.L. (1981), Creating the Corporate Future, Wiley, New York.

Ackoff, R.L. (1989), "The Circular Organization: An Update", Academy of Management Executive, Vol. 3, No. 1, pp. 11-16.

Ackoff, R.L. (1994), The Democratic Corporation, Oxford University Press, New York.

Atchison, T.J. (1991), "The Employment Relationship: Untied or Retied?", Academy of Management Executive, Vol. 5, No. 4, pp. 52-62.

Baron, R.A. and J.H. Neuman (1996), "Workplace Violence and Workplace Aggression:

Evidence on their Relative Frequency and Potential Causes", Aggressive Behavior, Vol. 22, pp. 161-173.

Blauner, R. (1964), Alienation and Freedom, University of Chicago Press, Chicago.

Carley, K. (1992), "Organizational Learning and Personnel Turnover", Organization Science, Vol. 3, pp. 20-46.

Clegg, S.R. (1989), Frameworks of Power, Sage, London.

Collinson, D. (1994), "Strategies of Resistance: Power, Knowledge and Subjectivity in the Workplace", in Jermier, J.M., Knights, D. and Nord, W.R. (Eds.), Resistance and Power in Organizations, Routledge, London, pp. 25-68.

Dahl, R. (1989), Democracy and Its Critics, Yale University Press, New Haven.

Daft, R.L. and Macintosh, N.B. (1984), "The Nature and Use of Formal Control Systems for Management Control and Strategy Implementation", Journal of Management, Vol. 10, pp. 4366.

Emery, F.E. (1980), "Designing Socio-Technical Systems for 'Greenfield' Sites", Occupational Behaviour, Vol. 1, pp. 19-27.

Emery, F.E. and Thorsrud, E. (1976), Democracy at Work, Leiden: Nijhoff.

Endenburg, G. (1988), Sociocracy: The Organization of Decision-making, Sociocratic Center, Rotterdam (Netherlands).

Endenburg, G. (1992), Sociocratie als Sociaal Ontwerp, Eburon, Delft (Netherlands).

Hardy, C. and S.R. Clegg (1996), "Some Dare Call It Power", in Clegg, S.R., Hardy, C. and Nord, W.R. (Eds.), Handbook of Organization Studies, Sage, London, pp. 622-641.

Hartley, J., Jacobsen, D., Klandermans, B. and Van Vuuren, T. (1991), Job Insecurity, Sage, Newbury Park. 
Hedlund, G. (1994), "A Model of Knowledge Management and the N-form Corporation", Strategic Management Journal, Vol. 15, Special issue 'Strategy: Search for New Paradigms', pp. 73-90.

Hirschhorn, L. (1990). The Workplace Within: Psychodynamics of Organizational Life, MIT Press, Cambridge.

Iannello, K.P. (1992), Decisions Without Hierarchy, Routledge, New York.

Jaques, E. (1990), "In Praise of Hierarchy", Harvard Business Review, Vol. 68, No. 1, pp. 127 133.

Jermier, J.M., Knights, D. and Nord, W.R. (1994), "Introduction", in Jermier, J.M., Knights, D. and Nord, W.R. (Eds.), Resistance and Power in Organizations, Routledge, London, pp. 1-24.

Katzner, D.W. (1995), "Participatory Decision-Making in the Firm", Journal of Economic Behavior and Organization, Vol. 26, pp. 221-236.

Knudsen, H. (1995), Employee Participation in Europe, Sage, London.

Likert, R. (1976), The Human Organization, McGraw-Hill, New York.

Louis, M.R. (1994), "In the Manner of Friends: Learning from Quaker Practice for Organizational Renewal", Journal of Organizational Change Management, Vol. 7, pp. 42-60.

Manz, C.C. and Sims, H.P. (1987), "Leading Workers to Lead Themselves: The External Leadership of Self-Managing Work Teams", Administrative Science Quarterly, Vol. 32, pp. 106-128.

McLagan, P. and Nel, C. (1995), The Age of Participation, San Francisco: Berret-Koehler, 1995.

Mulder, M. (1971), "Power Equalization Through Participation?", Administrative Science Quarterly, Vol. 16, pp. 31-38.

O'Connell-Davidson, J. (1994), "The Sources and Limits of Resistance in a Privatized Utility", in Jermier, J.M., Knights, D. and Nord, W.R. (Eds.), Resistance and Power in Organizations, Routledge, London, pp. 69-101.

Ouchi, W.G. (1981), Theory Z, Addison-Wesley, Reading.

Peters, T. (1987), Thriving On Chaos, Pan Books, London.

Pfeffer, J. (1992), Managing with Power: Politics and Influence in Organizations, Harvard Business School Press, Boston.

Reijmer, A. and A.G.L. Romme (1996), "Sturing en Zelforganisatie Volgens Sociocratische 
Principes", Argumenten, Vol. 17, No. 1, pp. 9-18.

Romme, A.G.L. (1995), "Making Organizational Learning Work: Consent and Double Linking Between Circles", European Management Journal, Vol. 14, pp. 69-75.

Romme, A.G.L. (1996), "A Note On the Team-Hierarchy Debate", $\underline{\text { Strategic Management }}$ Journal, Vol. 17, pp. 411-417.

Stewart, G.L. and C.C. Manz (1995), "Leadership for Self-Managing Work Teams: A

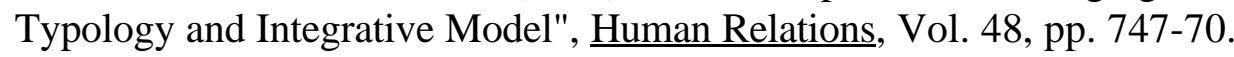

Van Vlissingen, R.F. (1991), "A Management System Based on Consent", Management, Vol. 10, pp. 149-154.

Vaughan, D. (1983), Controlling Unlawful Behavior: Social Structure and Corporate Misconduct, University of Chicago Press, Chicago.

Voyer, J.J. (1994), "Coercive Organizational Politics and Organizational Outcomes: An Interpretive Study", Organization Science, Vol. 5, pp. 72-85.

Wall, T.D. (1982), "Perspectives on Job Redesign", in Kelly, J.E. and Clegg, C.W. (Eds.), Autonomy and Control at the Workplace, Croom Helm, London, pp. 1-20.

Zeleny, M. (1989), "Knowledge as a New Form of Capital: Part 1. Division and Reintegration of Knowledge", Human Systems Management, Vol. 8, pp. 45-58. 
A. Georges L. Romme currently is associate professor in the Department of Management Sciences, Maastricht University, the Netherlands. He holds a masters degree in Economics from the University of Tilburg and a doctoral degree in Business Administration from Maastricht University.

\section{$\underline{\text { Introduction }}$}

Georges Romme, associate professor at Maastricht University (the Netherlands), explores a scenario for how work can be organized in a circular manner. Two tendencies in work relations are outlined: a return to authoritarian governance of the workplace, and at the same time, the inevitable and necessary shift toward more participation. Subsequently, the possibility of a synthesis of traditional and participative work relationships by organizing work in a circular manner is explored. Circularity implies that although authority may continues to play an important role in the workplace, an ultimate authority is absent, and each member can participate directly or through representation in decision processes which are organized in circles. 